Aquaculture

November 2005; 250(1-2) : 458-470

http://dx.doi.org/10.1016/j.aquaculture.2005.02.038

(C)2005 Published by Elsevier B.V.
Archimer, archive institutionnelle de l'Ifremer http://www.ifremer.fr/docelec/

\title{
Temperature and photoperiod drive Crassostrea gigas reproductive internal clock
}

\author{
Caroline Fabioux ${ }^{a^{*}}$, Arnaud Huvet $^{a}$, Pierrick Le Souchu $^{a}$, Marcel Le Pennec $^{b}$ \\ and Stéphane Pouvreau ${ }^{a}$
}

\author{
aUMR Physiologie et Ecophysiologie des Mollusques Marins, Ifremer, B.P.70, 29280 Plouzané, France \\ bUMR CNRS 6539, Laboratoire des Sciences de l'Environnement Marin, Université de Bretagne Occidentale, \\ IUEM, 29280 Plouzané, France \\ *: Corresponding author : Tel.: +33 2982246 93; fax: +33 2982246 53. Caroline.Fabioux@ifremer.fr
}

\begin{abstract}
This study examined the gametogenic cycle of Crassostrea gigas in controlled conditions over one year, with a focus on the initiation of gametogenesis. This work analysed also the role of temperature and photoperiod in the regulation of oyster reproduction. Broodstock were maintained in natural (NC), accelerated (AC) and perpetual winter (WC) conditions of temperature and photoperiod, with feeding ad libitum. Qualitative and quantitative analyses of the reproductive pattern were performed using biometric measurement approach, sex ratio determination, histology and a gonad filling index. Each experimental treatment led to different strategies for growth and resource allocation. The gametogenic cycle, appeared entirely modulated, accelerated or delayed, by coupled temperature/photoperiod parameters. Temperature played a key role in gonial mitosis regulation. Gonia proliferation was set off and sustained by winter temperature $\left(8-11{ }^{\circ} \mathrm{C}\right.$ ) whatever the physiological state of oysters. Maturation of germ cells appeared to be a function of temperature and could proceed at low temperature, while ripe oysters were obtained at $8{ }^{\circ} \mathrm{C}$ in winter conditioning. The three conditioning methods used in this study, allowed the production of gametes throughout the year, including in the autumnal resting period. Moreover, stocks of ripe oysters could be maintained at low temperature during several months to produce spat when desired for aquaculture production.
\end{abstract}

Keywords: Oyster; Reproduction; Gonial mitosis; Gonad filling index; Regulation; Temperature 


\section{Introduction}

Since its introduction to France in the 1970's (Grizel and Héral, 1991), the Pacific oyster Crassostrea gigas (Thunberg, 1789) has become the major farmed shellfish species. Juvenile supply for this industry was mainly obtained by spat collection from the natural environment in two sites, Marennes-Oléron and Arcachon basins (Robert and Gérard, 1999). The variability of spat recruitment from year to year and the recent increase of the market demand led to the development of hatchery spat production (Robert and Gérard, 1999). One of the key-steps in hatchery procedure is broodstock conditioning. It has been clearly shown that the fecundity in oysters could be controlled by manipulating its environment. Indeed, water temperature influenced gonadal development while food enhanced fertility and gamete quality (Loosanoff and Davis, 1963; Lannan et al., 1980; Muranaka and Lannan, 1984; Utting and Millican, 1997). Nevertheless different mechanisms of oyster reproduction remained unclear. The recurrent failure of autumn conditioning is a constraint to year-round hatchery production (Wilson, 1981; Le Pennec et al., 1998; Robert and Gérard, 1999). To overcome this limitation, it is necessary to obtain a wide overview, on an annual basis, of the oyster reproductive cycle and to understand its regulation by environmental parameters.

In nature, the annual reproductive cycle of $C$. gigas has been widely described (Perdue, 1982; Maurer and Borel, 1986; Dinamani, 1987; Ruiz et al., 1992; Barber, 1996; Steele and Mulcahy, 1999; Berthelin et al., 2000; Lango-Reynoso et al., 2000; Li et al., 2000; Chavez-Villalba et al., 2001; Ren et al., 2003). A general pattern of oyster reproduction in relation with environmental parameters might be drawn accordingly. In temperate regions, C. gigas exhibited a seasonal reproductive cycle, clearly related to temperature with (1) initiation of gametogenesis usually observed in winter when water temperature was low; (2) active phase of gametogenesis (growing stage) in spring when water temperature increased; (3) maturity and spawning in summer, when temperature was above $19^{\circ} \mathrm{C}$ (Mann, 1979); (4) resorption period in autumn (degenerating stage). Gametogenesis has been also influenced by salinity with negative effects at low values ( $\leq 30 \mathrm{ppt}$ ) (Muranaka and Lannan, 1984). This general pattern could also be modulated by food availability in the surroundings. In eutrophic environments oysters produced more gametes than in poorer environments (Kang et al., 2000). The major drawback in field measurements was that the role of each environmental parameter in reproductive processes could not be assessed. Alternatively, studies on the effect of external parameters on C. gigas gametogenesis in controlled environments (i.e. broodstock conditioning) are scarce and only short term (Muranaka and Lannan, 1984; See also Robinson, 1992 for C. gigas kumamoto; Chavez-Villalba et al., 2002a; Chavez-Villalba et al., 2002b). Moreover, these studies focused mainly on the maturation of germ cells and very few on the initiation of the reproductive cycle whereas it has been a crucial step for the following gametogenesis.

We report in this study the influence of natural, accelerated temperature and photoperiod cycles and perpetual winter conditions on gametogenesis of $C$. gigas, including the initiation of the reproductive cycle, maturation and gamete resorption.

\section{Materials and methods}

\section{Biological material}

Oysters were hatchery produced in 2001 in the Ifremer hatchery in La Tremblade (France) from 30 wild broodstock collected in the Marennes-Oléron Bay. Spat were then reared at the Ifremer station in Bouin (France). One-year-old oysters were conditioned at the 
Ifremer shellfish laboratory in Argenton (France) from February 2002 to February 2003, in 600 -L raceways with $20 \mu \mathrm{m}$-filtered running seawater. Oysters were fed ad libitum with a mixed diet of three micro-algae equal to $8 \%$ dry weight algae/dry weight oyster per day and per oyster (33\% Chaetoceros calcitrans and Skeletonema costatum, 33\% Isochrysis affinis galbana, 33\% Tetraselmis chui). During the experimental period, mean salinity was $34.5 \mathrm{ppt}$ while water temperature was controlled every day. Twice a week, raceways were drained, cleaned and dead animals counted and removed. Three experimental conditionings were assayed. In the first one, related to natural conditions (NC), temperature and photoperiod were regulated to follow the mean natural cycles recorded in Marennes-Oléron Bay during the last ten years (Figure 1) (Soletchnik et al., 1998). In the second one, temperature and photoperiod cycles were accelerated to twice that of the natural cycle (NC) and was referred to as accelerated conditioning (AC). The third treatment maintained winter conditions, $8{ }^{\circ} \mathrm{C}$ and 8 daylight and was called winter conditioning (WC).

Twenty oysters were initially collected in February 2002 and randomly sampled every month in each condition (NC, AC, WC) from March 2002 to August 2002. From September 2002 to February 2003, only fifteen oysters per condition were sampled due to significant mortality in spring and summer 2002 in NC batches.

Figure 1: Mean monthly values of temperature and photoperiod applied in natural (black line), accelerated (grey dotted line) and wintering (black dotted line) experimental conditions (NC, AC and WC).
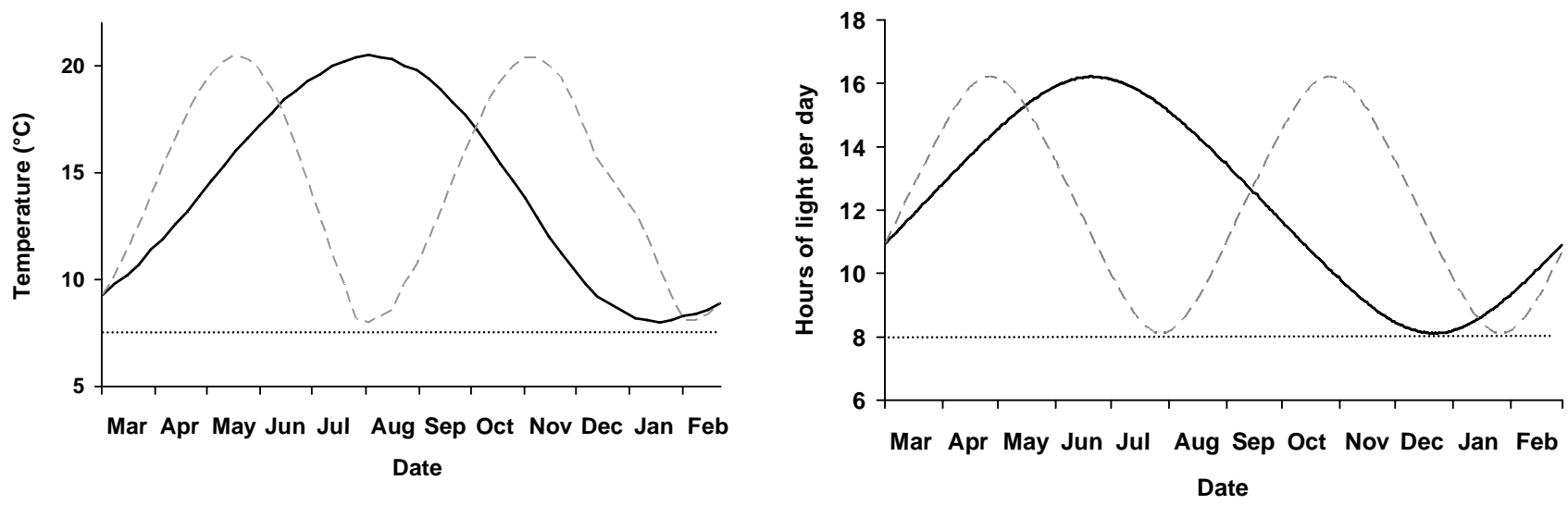

\section{Biometry and condition Indices}

Total wet weight, shell length and visceral mass (digestive gland, gonad and labial palps) wet weight were measured as well as the condition index (CI) corresponding to visceral mass wet weight / total wet weight.

\section{Qualitative reproductive analysis}

For each sample, adductor muscle, gills and mantle were removed and 3-mm cross section of the visceral mass were excised in front of the pericardic region for histological examination and immediately fixed in Davidson's solution (Shaw and Battle, 1957) at $4^{\circ} \mathrm{C}$ for 48 h. Sections were dehydrated in ascending ethanol solutions, cleared with xylene and 
embedded in paraffin wax. Five- $\mu$ m thick sections were cut, mounted on glass slides, stained with Harry's hematoxylin-Eosin Y (Martoja and Martoja-Pierson, 1967). Slides were examined under a light microscope to determine the sex and gametogenic stage according to the reproductive scale reported by Steele and Mulcahy (1999).

\section{Quantitative reproductive analysis}

Each slide was scanned with HP Scanjet 6300 C scanner at magnification X400. The gonad area (GA) relative to the whole area of the visceral mass was determined by the image analysis software IMAQ Vision Builder (National Instrument). This analysis, based on specific coloration intensity of different tissues of the histological slides, was performed with the following script: (1) Colour images were transformed to grey level images by means of the "colour extraction" function, (2) the outlines of the histological section were defined by drawing with the "image mask" function, (3) the area of one tissue (gonad, digestive gland or conjunctive tissue) was determined by adjusting the grey level threshold specific for this tissue, (4) the area of the tissue was automatically calculated in pixels (Heffernan and Walker, 1989).

\section{Statistical analysis}

Differences between biometric parameters (total weight, shell length and visceral mass weight), condition indices and percentage of gonad area in three conditionings were tested using the non-parametric Kruskal-Wallis analysis at $\mathrm{p}<0.05$. Chi-square statistics were used to test sex ratios against a 1:1 ratio.

\section{Results}

\section{Biometric measurements}

Total wet weight, shell length and visceral mass increased all over the year (Figure 2). At the end of the experiment (January 2003), mean total weight of oysters from AC was higher $(59.5 \mathrm{~g} \pm 19)$ than that of oysters from NC and WC (47.7 $\mathrm{g} \pm 19$ and $37.2 \mathrm{~g} \pm 13$, respectively) (Figure 2A) with significant differences between WC and AC (Kruskall-Wallis test value=17.22, $\mathrm{p}<0.05, \mathrm{~N}=45$ ). The same pattern was observed for shell length measurements with oysters from AC significantly higher $(9.5 \mathrm{~cm} \pm 1.6)$ than those from NC and WC $(7.7 \mathrm{~cm} \pm 1.0$ and $7.2 \mathrm{~cm} \pm 1.1$, respectively) (Kruskall-Wallis test value $=18.86$, $\mathrm{p}<0.05, \mathrm{~N}=45$ ) (Figure 2B). In contrast, no significant differences were observed for the mean visceral mass weight between different experimental conditions (4.2 $\pm 1.9 ; 4 \pm 1.4 ; 4.8 \pm 1.8$, for NC, AC, WC, respectively) in January 2003 (Figure 2C).

In NC, condition index (CI) increased from February to June, decreased after spawning induced in June by adding mature gonad extract in raceways. CI increased again from August to the end of the experiment (Figure 3). In AC, CI slightly increased from February to May, decreased after induced spawning in May and increased again from July to the end of the experiment (Figure 3). In WC, CI increased regularly all over the year (Figure 3). In January 2003, significant differences were recorded for the CI of oysters exposed to the different environmental conditions (Kruskall-Wallis test value $=23.66, \mathrm{p}<0.05, \mathrm{~N}=45$ ), with WC oysters exhibiting the highest value (13.2 \pm 2.6$)$. 
Figure 2: Mean biometric data evolution of Crassostrea gigas exposed to natural, accelerated and wintering conditions (NC, AC and WC). (A) Total wet weight; (B) Shell length; (C) Visceral mass wet weight. Bars represent standard deviation.
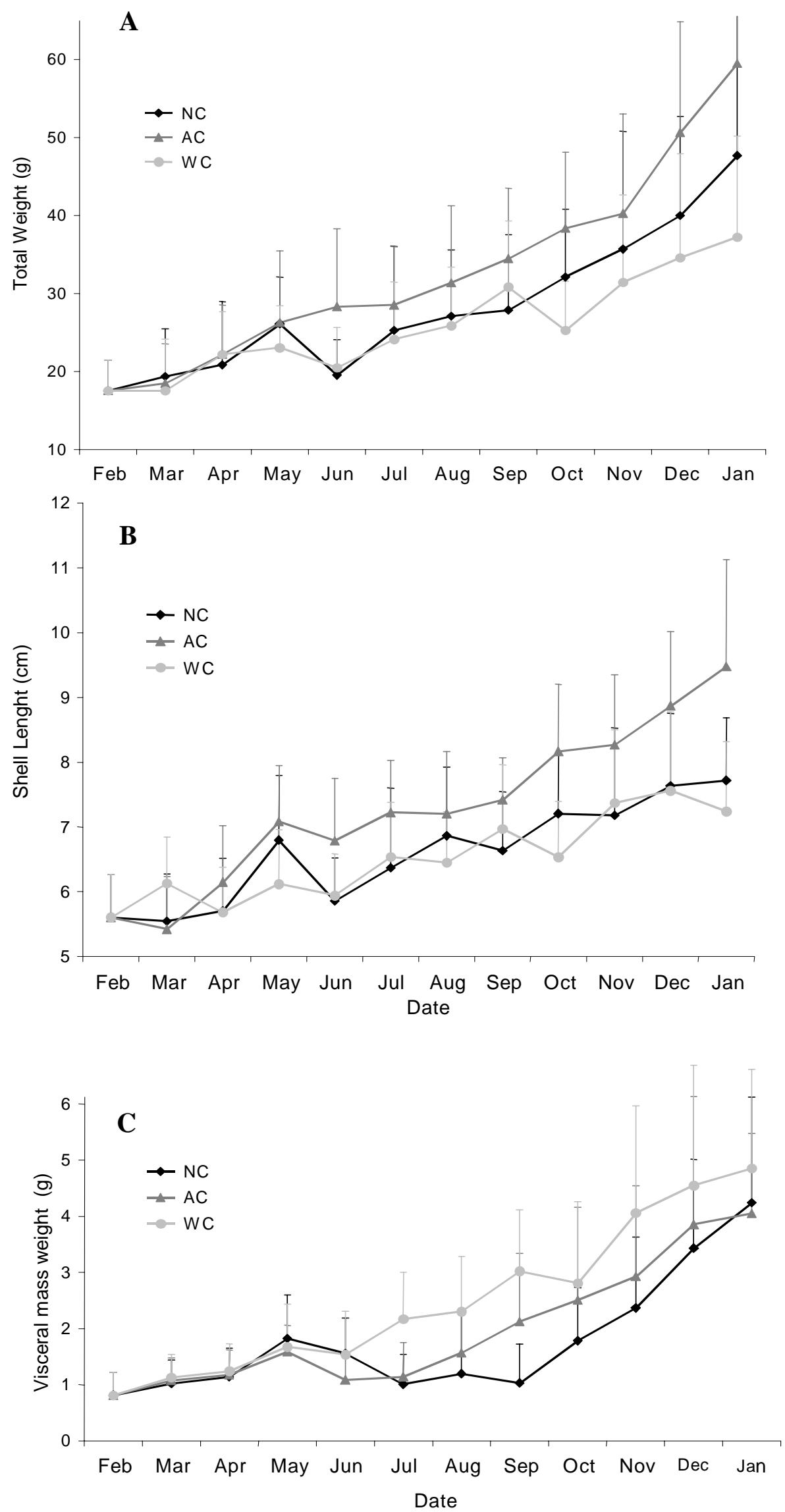
Figure 3: Evolution of the condition index (CI) of Crassostrea gigas oysters exposed to natural, accelerated and wintering conditions (NC, AC, WC). Bars represent standard deviation.

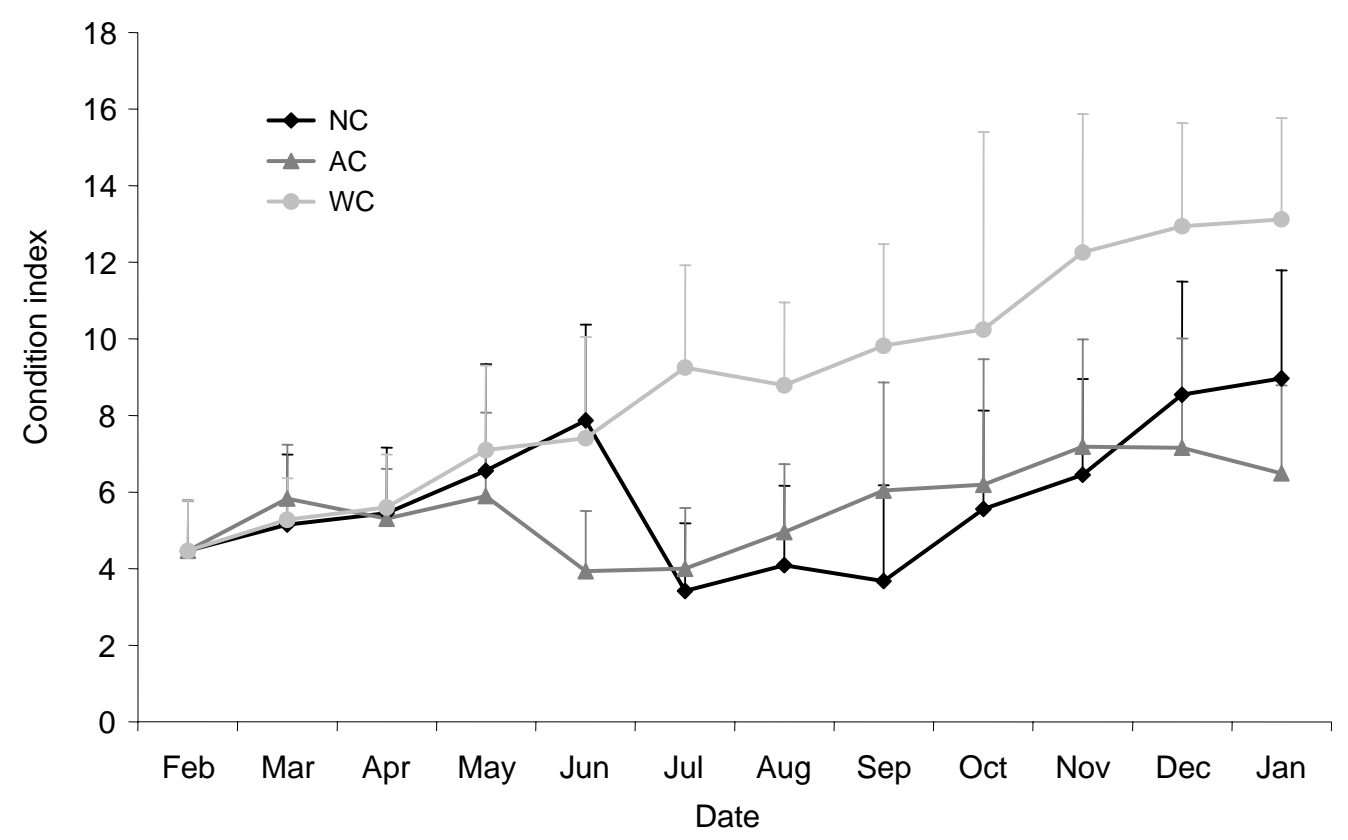

Sex ratio

Sex ratios (number of female: number of male) changed throughout the year in the three conditions. Nevertheless, when computing all data, sex ratios were 1:1.3 for NC, 1:1 for AC, and 1:1.6 for WC with no significant difference from 1:1 in NC and AC conditions but clearly significant for WC. Three and six hermaphrodites were recorded all over the reproductive cycles in NC and AC, respectively.

The number of undifferentiated animals varied in NC, AC and WC samples. Only one undifferentiated oyster was found in WC, in March. In NC, undifferentiated oysters were found in March (2) and April (1) and in relative abundance (27) from August to January 2003. In AC, undifferentiated oysters were found in March (2) and from July to January 2003 (7).

\section{Gametogenic cycle: quantitative analysis}

The development of gonad area (GA) of oysters exposed to different experimental conditions is reported in figure 4. The initial mean GA value was $6.1 \%$. Under NC, the overall pattern was clearly monomodal with increasing values from March (7.1\%) to June (55.3\%), then decreasing after spawning until November (9.7\%) to remain constant afterwards. Under AC, oyster gonad area increased more rapidly than in NC and followed a clear binomial pattern. In May, a first maximum value was recorded (63.5\%) while the lowest gonad area was detected in July (11.7\%). In November a second maximum value (53.1\%) was noted but Kruskall-Wallis test showed no significant differences between these two peaks $(\mathrm{F}=2.34$, $\mathrm{p}>0.05, \mathrm{~N}=30$ ). Under $\mathrm{WC}$, the overall pattern showed a gradual increase in gonad area throughout the experiment with a maximum value of $62 \%$ in November. Despite these different patterns, no significant differences were observed between maximum values whatever experimental conditions (Kruskall-Wallis test value $=0.72, \mathrm{p}>0.05, \mathrm{~N}=57$ ). 
Figure 4: Evolution of the percentage of gonad area (/visceral mass total area) in natural, accelerated and wintering conditions (NC; AC; WC). For AC, a bold initial letter under the "date" axis represents the artificial months for oysters obtained with accelerated conditions. Bars represent standard deviation.
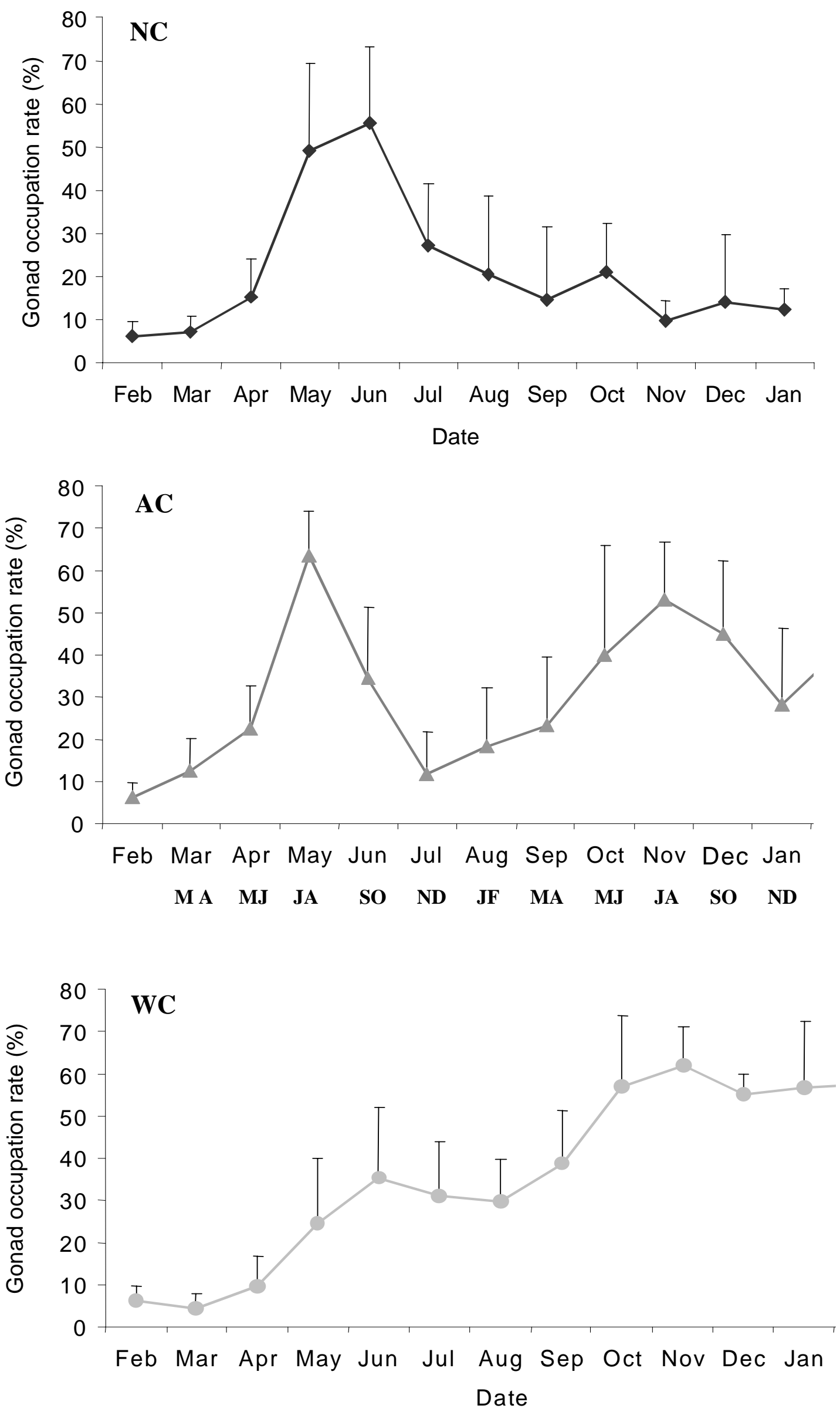


\section{Gametogenic cycle: qualitative analysis}

The oyster germ cell development in NC, AC and WC was analysed by histology. Five characteristic periods of the reproductive cycle (initiation, maturation, ripeness, after spawning, resorption) were reported in plates 1 and 2. In February 2002, oyster gonads consisted of very small follicles filled with stem cells, widely separated by connective conjunctive tissue. Sex of oysters was indistinguishable at this stage (data not shown).

In April, gonad of females from NC and WC (Plates 1A and 1C) were at the same gametogenic stage: tubule walls contained mainly stem cells and oogonia characterised by compact, large nuclei $(6 \mu \mathrm{m})$ and a narrow rim of finely granular cytoplasm. Conjunctive connective tissue was abundant. A similar pattern was observed for males from NC and WC (Plates 2A and 2C). Tubules contained mainly stem cells, spermatogonia and young smaller spermatocytes. Connective tissue was also abundant. In April, females and males from AC were at a later developmental stage compared to those observed in NC and WC (Plates 1B and 2B). In females, tubules consisted in vitellogenic oocytes, cells $30-45 \mu \mathrm{m}$ in diameter with distinct nuclei, attached to tubule walls or free in the lumina (Plate 1B). In males, tubules contained different germ cell stages, spermatocytes, spermatids and spermatozoa, decreasing in size from the outer wall to the centre of the tubule. Spermatozoa possessed flagella and were free in the lumina of the tubules (Plate 2B).

In May, oysters from NC were clearly in maturation stage (Plate 1D). Female tubules were filled with attached oocytes and a large number of free oocytes (Plate 1D). Male tubules were filled with spermatozoa, while germinal epithelia always showed spermatids (Plate 2D). In May, oysters from AC were ripe, female tubules were filled with free mature oocytes and male tubules were filled with spermatozoa (Plates $1 \mathrm{E}$ and $2 \mathrm{E}$ ). In contrast, oysters from the $\mathrm{WC}$ at the same period were still at early developing stage (Plates $1 \mathrm{~F}$ and $2 \mathrm{~F}$ ). Female germinal follicles contained some vitellogenic oocytes but most part of cells were oogonia or young oocytes (Plate $1 \mathrm{~F}$ ). In males, first spermatozoa appeared but gonadal tubules mainly consisted in spermatocytes and spermatids (Plate 2F).

In August, oysters from NC were partially or totally spent. In Plate 1G, female was totally spent, only rare oocytes stayed in empty tubules. Connective tissue was disorganised and invaded by blood cells. In Plate 2G, male was partially spent, some spermatozoa remained in discharging tubules. In August, oysters in AC were spent and a new reproductive cycle had been reinitiated (Plates $1 \mathrm{H}$ and $2 \mathrm{H}$, Figure 5). Plate $2 \mathrm{H}$ represented the initiation of the reproductive cycle. Small clusters of stem cells were isolated among conjunctive tissue. In figure 5, lumina of gonadic tubules of AC oysters were filled with residual spermatozoa while tubule walls consisted in spermatogonia and spermatocytes (Figure 5A) or oogonia (Figure 5B). In August, oysters from WC were still in maturation stage (Plates 1I and 2I). In females, the follicle size increased and more free oocytes were observed in tubules but oogonia were still observed. Conjunctive tissue remained visible (Plate 1I). In the same way the number of spermatozoa increased in males but spermatocytes and spermatids still remained. Conjunctive tissue was observed between developing tubules (Plate 2I).

In October, oysters from NC were in regression (Plates $1 \mathrm{~J}$ and $2 \mathrm{~J}$ ). Conjunctive connective tissue was disorganised and processes of cytolysis were observed both in female and male tubules. At this time, oysters from AC were in maturation as described in May for oysters from NC (Plates $1 \mathrm{~K}$ and $2 \mathrm{~K}$ ) while oysters from WC were ripe (Plates $1 \mathrm{~L}$ and $2 \mathrm{~L}$ ). Female tubules were filled with mature oocytes and male tubules with spermatozoa but earlier stage germ cells (oogonia and young oocytes or spermatogonia and spermatocytes) still remained (Plates $1 \mathrm{~L}$ and $2 \mathrm{~L}$ ).

Lastly, at the end of the experiment (January 2003), oysters from NC were at the initiation phase of the reproductive cycle (Plates $1 \mathrm{M}$ and $2 \mathrm{M}$ ). Oysters from AC were spent, 
totally or partially (Plates $1 \mathrm{~N}$ and $2 \mathrm{~N}$ ) and oysters from WC were ripe with early stage germ cells still observed in the tubule walls (Plates $1 \mathrm{O}$ and 2O).

Figure 5: Gonadic tubules of oysters, sampled in August, issued from accelerated conditioning (AC) contained two successive generations of germ cells. Residual spermatozoa in lumina of tubules represented old generation of germ cells while the new one, male (A) or female (B), was located on the tubule wall. Spmz: spermatozoa, Spm: spermatogonia and spermatocytes, Oog: oogonia. Scale bar 50 um.
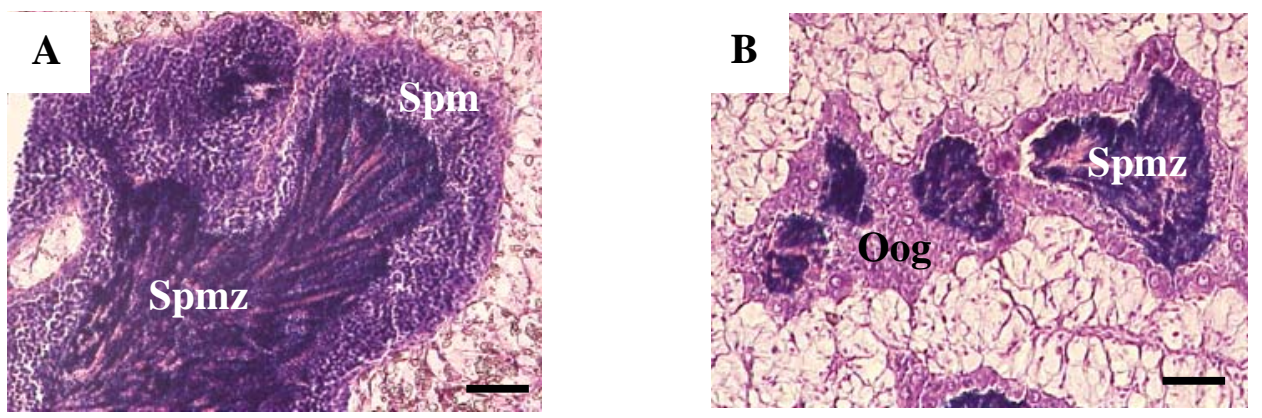

Plate 1: Histological description of $C$. gigas female reproductive cycle in natural (NC), accelerated (AC) and wintering conditions (WC). Ct: conjunctive tissue, SC: stem cells, Oog: oogonia, Ooc: young oocyte, Vooc: vitellogenic oocyte, Mooc: mature oocyte, Rooc: residual oocyte, RP: products of resorption, Fc: follicle cells, Dg: digestive gland.

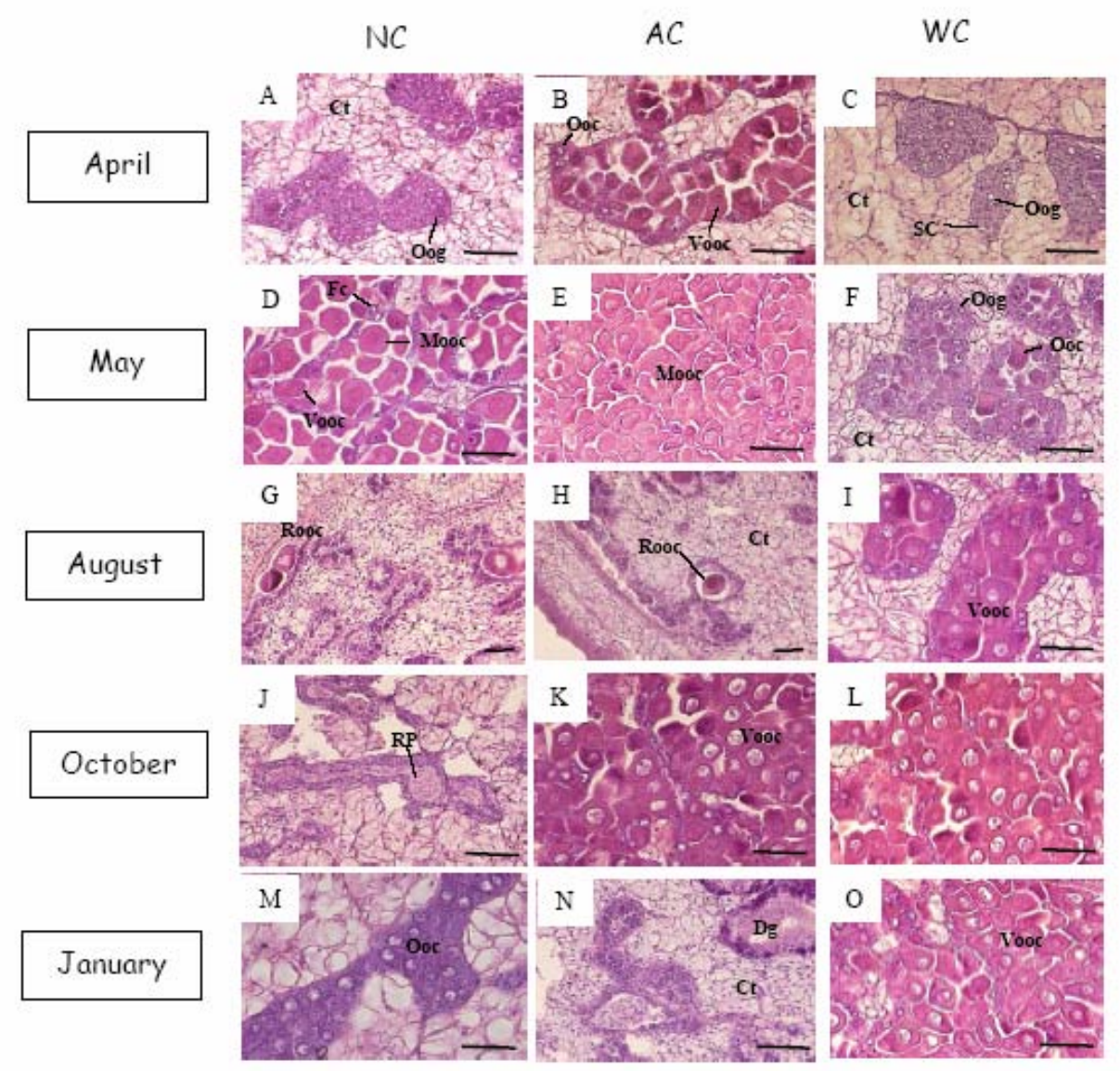


Plate 2: Histological description of $C$. gigas male reproductive cycle in natural (NC), accelerated (AC) and wintering conditions (WC). Ct: conjunctive tissue, Spg: spermatogonia, Spc: spermatocytes, Spt: spermatids, Spz: spermatozoa, Rspz: residual spermatozoa, PR: products of resorption, Dg: digestive gland, Bc: blood cells.

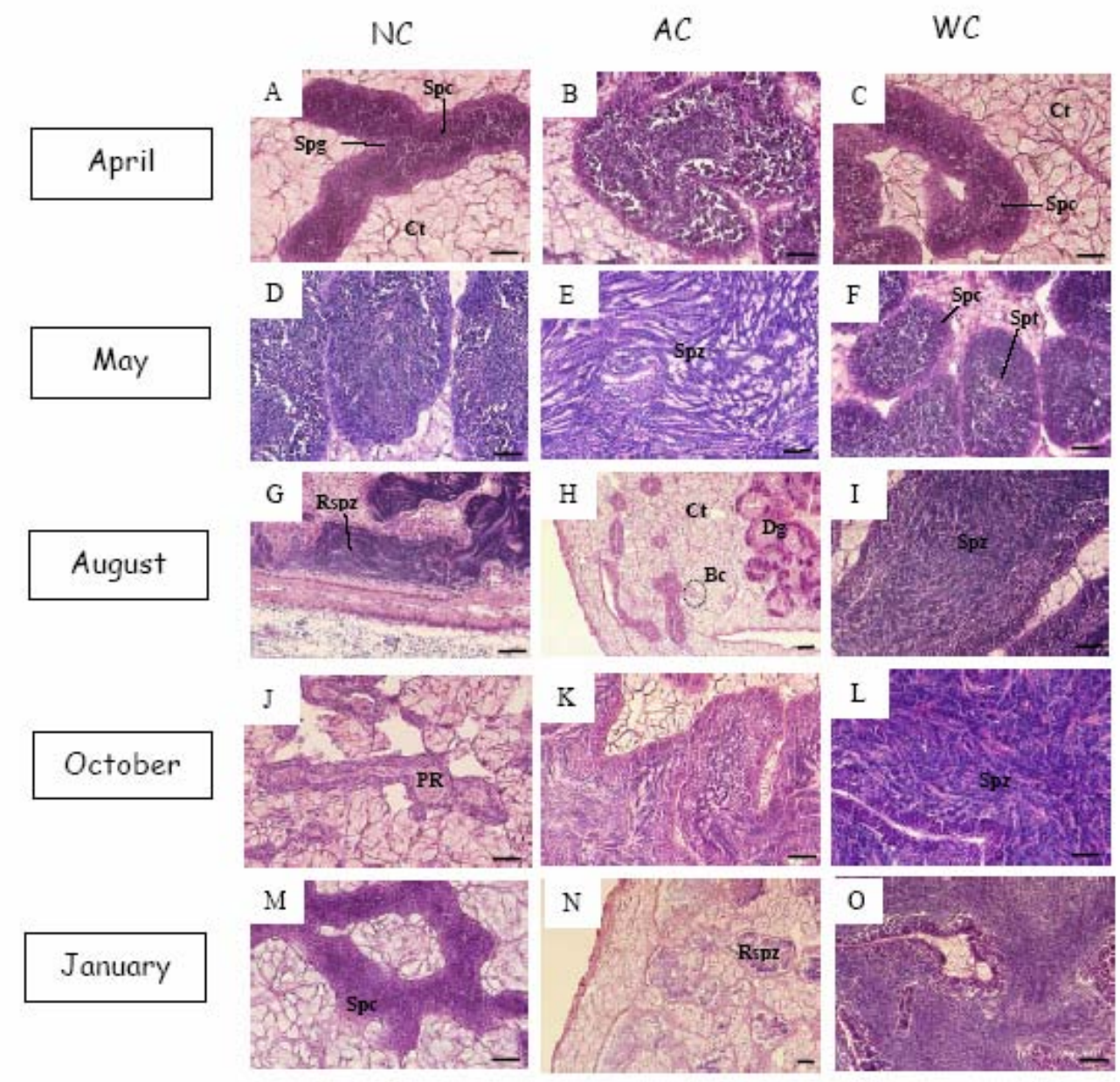

\section{Discussion}

Up to now, studies on the reproduction of $C$. gigas and its regulation by environmental parameters in controlled conditions were restricted in time and mainly focused on studying the maturation phase (Muranaka and Lannan, 1984; Robinson, 1992; Chavez-Villalba et al., 2002b). Data on complete reproductive cycle of $C$. gigas were only available in natural environment. These studies were very useful to analyze the environment-dependent strategy of C. gigas, but did not specify the importance of each environmental parameter. This study analyzed the effect of temperature coupled with photoperiod on reproduction during a complete annual cycle in controlled environment. This long-time conditioning constituted a really new approach. The large scale of this experimental plan prevented us from testing 
independently the effect of temperature and photoperiod. Nevertheless, any effect of photoperiod on C. gigas reproductive process has never been put in evidence.

The biometric measurements, performed throughout the experiment, clearly showed that oysters fed with the same food (in term of quantity and quality) but placed in natural, accelerated or wintering conditions developed different strategies for growth and resource allocation. At the end of the trials, oysters conditioned under accelerated conditions had the highest mean total weight (around $60 \mathrm{~g}$ ) and shell length (around $9.5 \mathrm{~cm}$ ) but the lowest condition index. In contrast, oysters conditioned under wintering conditions showed the lowest total weight (around $35 \mathrm{~g}$ ) and shell length (around $7.2 \mathrm{~cm}$ ) but the highest condition index. Oysters maintained under natural conditions were in an intermediate position for all parameters. The lack of spawning of oysters in WC presumably explains its high condition index compared to the other conditions whereas its total weight was lower. For oysters in WC, resource allocation would be in favour of gonad growth, as they stayed in running gametogenesis during a large part of the experiment without spawning. At the opposite, oysters from AC, and NC in a lower degree, seemed to be able to invest more in somatic growth compared to oysters in WC, as they had reproductive resting period. Compared to other invertebrates or marine animals, priority rules in bivalves energy allocation between somatic growth, gametogenesis and maintenance remain unclear (Ernande et al., 2004). In this study, balance between somatic and gonad growth appeared modulated by temperature and switches in resource allocation between both compartments would be driven by spawning events.

The qualitative and quantitative analysis of gametogenic cycle in three environmental conditions demonstrated the high physiological plasticity in C. gigas reproductive process (Ernande et al., 2004). Oysters maintained in the laboratory under natural conditions (NC) followed the same gametogenic pattern as oysters reared in Marennes-Oléron bay (DeslousPaoli et al., 1981). In other conditions (accelerated and winter) the gametogenic pattern of oysters appeared entirely modulated by coupled temperature / photoperiod parameters. In winter conditions (WC), the gametogenic cycle was slowed down; gametogenesis proceeded slowly through initiation to maturation stage (October-January). In contrast, under accelerated conditions (AC), oysters performed two complete gametogenic cycles in one year. A maturation phase occurred during both "artificial springs" (March-May and SeptemberNovember) and two spawning periods were subsequently observed.

In natural cycle, resorption or "atresia" of unspawned gametes was observed in autumn. This process was clearly described in C. gigas by Steele and Mulcahy (1999). It has been generally assumed that resorption occurred after a partial spawning event to "clean" the gonad and prepare it for a new cycle. In the accelerated conditions, the delay between spawning in May (corresponding to natural conditions of August) and the beginning of "artificial autumn" in June-July was very short. Regression of unspwaned gametes has not been completed while proliferation of stem cells began in July (corresponding to November in nature). These two processes (degeneration and re-initiation) occurred at the same time in the gonad where two generations of germ cells could be simultaneously observed (Figure 5). These observations seemed to indicate that gamete resorption is a dispensable step for the reinitiating of a new reproductive cycle.

The kinetic and regulation of gonial mitosis at the initiation of the reproductive cycle remained unknown for a long time in C. gigas. The proliferation of gonia was previously described in natural conditions using a molecular marker specific of oyster germ cells, the oyster vasa-like gene (Fabioux et al., 2004). It was shown that the multiplication of gonia occurred from November to March. In the present study, gonial mitosis appeared to be clearly regulated by temperature. Gonia proliferation was triggered on by low temperatures, between $8{ }^{\circ} \mathrm{C}$ and $11^{\circ} \mathrm{C}$, whatever physiological state of oysters, while this process occurred both 
during decreasing and increasing photoperiod phase. Gonia proliferation occurred in AC while unspawned gametes have not been yet resorbed (Figure 5) and continued as long as temperature remained low. Gonia were observed throughout the year, including in ripe oysters, in WC. Moreover, gametogenesis initiation was demonstrated to begin under $10{ }^{\circ} \mathrm{C}$ unlike data given in previous studies (Mann, 1979). Further studies, using the oyster vasa-like gene as a marker to quantify the proliferation of gonia in NC, AC and WC, would be of great interest to assess the role of environmental parameters in the regulation of the number of gonial mitosis.

Ripe oysters were obtained after 4 months, 3 months and 8 months in natural, accelerated and wintering conditions, respectively. These results showed that the maturation of oyster germ cells is a function of temperature as suggested by Muranaka and Lannan (1984). This relation is in agreement with the "day-degrees" notion proposed by Mann (Mann, 1979) except that minimal temperature for oyster gametogenesis would be lower than $10{ }^{\circ} \mathrm{C}$. However, there is not maturation threshold temperature as supposed by Ruiz et al. (1992). We obtained ripe oysters at $8-10{ }^{\circ} \mathrm{C}$ in wintering conditioning while Ruiz et al. (1992) indicated that a threshold of $16{ }^{\circ} \mathrm{C}$ was required to enhance germ cells maturation.

Autumn has been often described as a critical period for bivalve conditioning (Wilson, 1981; Le Pennec et al., 1998; Robert and Gérard, 1999). Chavez-Villalba et al. (2002a) succeeded in producing $C$. gigas mature oocytes in autumn with oysters kept in winter conditions during three months and then conditioned at $19^{\circ} \mathrm{C}$ for seven weeks. In this study, we showed that $C$. gigas oysters placed in accelerated conditions produced mature oocytes and spawned twice a year included in autumn. After first spawning event, oysters conditioned under accelerated cycle of temperature realized storage accumulation and germ cell stock reconstitution, two essential steps for reproduction. Inversely, in conditionings under high constant temperature, oysters sampled in nature after spawning could not reconstitute their stock of germ cells, which prevent animals from doing gametogenesis. In this study, the autumn spawning event was less intensive than the summer spawning. This decrease in the intensity of gamete emission was usually observed in nature in case of autumn spawning following to one or both summer spawning events.

A significant increase of males was recorded in wintering conditions. The Pacific oyster is a protandric hermaphrodite species, but few data are available on sex determination in C. gigas (Guo et al., 1998). Sex determination in oyster is genetically controlled and influenced by environmental factors, despite scarce information on that latter. Males are supposed to predominate when the environment is less favorable (Steele and Mulcahy, 1999). Conversely, females would be preferentially found in a rich environment. Nevertheless, this theory has not been clearly demonstrated (Baghurst and Mitchell, 2002). In our study, the food level could not explain the excess of male in WC since populations were fed with the same food in quantity and quality. Conversely, temperature could be one of the main factors controlling sex determination and constant low water temperature in WC could explain in a large part the excess of males.

In conclusion, we demonstrated in this study that, in condition of optimal food level, temperature and/or photoperiod drive reproductive internal-clock of C. gigas, in particular for the regulation of gonial proliferation and germ cell maturation, both essential steps in oyster reproduction. The modification of these environmental parameters led to complete modification of the timing of $C$. gigas gametogenesis.

Using the three methods described in this study (NC, AC and WC), ripe oysters could be obtained throughout the year. The wintering conditions developed in this study could be a new method to maintain a stock of ripe gametes for several months since they stayed in a ripe state for at least 5 months (from October to the end of the experiment) without any sign of gamete resorption. Moreover, the fertility of these gametes was confirmed by experimental 
crosses using stripped gametes of WC oysters. For hatchery applications, studies on growth, survival rates and metamorphosis of larvae issued from broodstock conditioned in natural, accelerated and wintering conditions would allow the validation of these methods to produce spat throughout the year.

\section{Acknowledgements}

The authors are grateful to all staff of the Ifremer stations of the Argenton, and particularly to J.P. Connan and B. Leroy for micro-algae production, La Tremblade, especially to L. Dégremont for producing oysters, and Bouin for providing and conditioning oysters. We acknowledge R. Robert (UMR PE2M, Ifremer Brest, France) for his helpful comments and for his help in editing the English language of the manuscript. This work was supported by a specific financial grant provided by the Ifremer scientific department as part of the program focusing on the reproduction of C. gigas. 


\section{References}

Baghurst, B., Mitchell, J. (2002) Sex specific growth and condition of Pacific Oysters (Crassostrea gigas Thunberg). Aquacult. Res. 33, 1253-1263.

Barber, B.J. (1996) Gametogenesis of eastern oysters, Crassostrea virginica (Gmelin, 1791), and Pacific oysters, Crassostrea gigas (Thunberg, 1793) in disease-endemic lower Chesapeake Bay. J. Shellfish Res. 15, 285-290.

Berthelin, C., Kellner, K., Mathieu, M. (2000) Storage metabolism in the Pacific oyster (Crassostrea gigas) in relation to summer mortalities and reproductive cycle (west coast of France). Comp. Biochem. Physiol., B 125, 359-369.

Chavez-Villalba, J., Barret, J., Mingant, C., Cochard, J.C., Le Pennec, M. (2002a) Autumn conditioning of the oyster Crassostrea gigas: a new approach. Aquaculture 210, 171186.

Chavez-Villalba, J., Pommier, J., Andriamiseza, J., Pouvreau, S., Barret, J., Cochard, J.C., Le Pennec, M. (2002b) Broodstock conditionning of the oyster Crassostrea gigas: origin and temperature effect. Aquaculture 214, 115-130.

Chavez-Villalba, J.E., Mingant, C., Cochard, J.C., Le Pennec, M. (2001) Gamétogenèse chez l'huître Crassostrea gigas de l'Aber benoït (Bretagne, France), à la limite nord de son aire de reproduction. Haliotis 30, 1-12.

Deslous-Paoli, J.M., Heral, M., Berthome, J.P., Razet, D., Garnier, J. (1981) Natural reproduction of Crassostrea gigas (Thunberg) in Marennes-Oleron basin in 1979 and 1981: Biochemical and energetic aspects. Rev. Trav. Inst. Peches Marit. Nantes 45, 319-327.

Dinamani, P. (1987) Gametogenic patterns in populations of Pacific oyster, Crassostrea gigas, in Northland, New Zealand. Aquaculture 64, 65-76.

Ernande, B., Bourdry, P., Clobert, J., Haure, J. (2004) Plasticity in resource allocation based life history traits in the Pacific oyster, Crassostrea gigas. I. Spatial variation in food abundance. J. Evol. Biol. 17, 342-356.

Fabioux, C., Pouvreau, S., Le Roux, F., Huvet, A. (2004) The oyster vasa-like gene: a specific marker of the germline in Crassostrea gigas. Biochem. Bioph. Res. Com. 315, 897904.

Grizel, H., Héral, M. (1991) Introduction into France of the Japanese oyster (Crassostrea gigas). J. Cons. CIEM 47, 399-403. 
Guo, X., Hedgecock, D., Hershberger, W.K., Cooper, K., Allen, S.K. (1998) Genetic determinants of protandric sex in the Pacific oyster, Crassostrea gigas. Evolution 52, 394-402.

Heffernan, P.B., Walker, R.L. (1989) Quantitative image analysis methods for use in histological studies of bivalve reproduction. J. Mollusc. Stud. 55, 135-137.

Kang, C.-K., Park, M.S., Lee, P.-Y., Choi, W.-J., Lee, W.-C. (2000) Seasonal variations in condition, reproductive activity, and biochemical composition of the Pacific oyster, Crassostrea gigas (Thunberg), in suspended culture in two coastal bays of Korea. J. Shellfish Res. 19, 771-778.

Lango-Reynoso, F., Chavez-Villalba, J., Cochard, J.C., Le Pennec, M. (2000) Oocyte size, a means to evaluate the gametogenic development of the Pacific oyster, Crassostrea gigas (Thunberg). Aquaculture 190, 183-199.

Lannan, J.E., Robinson, A.K., Breese, W.P. (1980) Broodstock management of Crassostrea gigas: II. Broodstock conditioning to maximise larval survival. Aquaculture 21, 337345.

Le Pennec, M., Robert, R., Avendano, M. (1998) The importance of gonadal development on larval productions in pectinids. J. Shellfish Res. 17, 97-101.

Li, K., Osada, M., Mori, K. (2000) Seasonal biochemical variations in Pacific oyster gonadal tissue during sexual maturation. Fisheries Sci. 66, 502-508.

Loosanoff, V.L., Davis, H.C. (1963) Rearing of bivalve molluscs. Adv. Mar. Biol. 1, 1-136.

Mann, R. (1979) Some biochemical and physiological aspects of growth and gametogenesis in Crassostrea gigas and Ostrea edulis grown at sustained elevated temperatures. $J$. Mar. Biol. Assoc. U.K. 59, 95-110.

Martoja, R., Martoja-Pierson, M. (1967) Initiation aux techniques de l'histologie animale, Paris, 1232 pp.

Maurer, D., Borel, M. (1986) Croissance, engraissement et cycle sexuel de Crassostrea gigas dans le bassin d'Arcachon : comparaison des huîtres agées de 1 et 2 ans. Haliotis 15, 125-134.

Muranaka, M.S., Lannan, J.E. (1984) Broodstock management of Crassostrea gigas : Environmental influences on broodstock conditioning. Aquaculture 39, 217-228. 
Perdue, J.A. (1982) Gametogenesis and growth of the Pacific oyster Crassostrea gigas (Thurnberg). J. Shellfish Res. 2, 105-106.

Ren, J.S., Marsden, I.D., Ross, A.H., Schiel, D.R. (2003) Seasonal variation in the reproductive activity and biochemical composition of the Pacific oyster (Crassostrea ؛ $B$ I from the Malborough Sounds, New Zeland. New Zeal. J. Mar. Fresh. Res. 37, $1,1-182$.

Robert, R., Gérard, A. (1999) Bivalve hatchery technology: the current situation for the Pacific oyster Crassostrea gigas and the scallop Pecten maximus in France. Aquat. Living Resour. 12, 121-130.

Robinson, A. (1992) Gonadal cycle of Crassostrea gigas kumamoto (Thunberg) in Yaquina Bay, Oregon and optimum conditions for broodstock oysters and larval culture. Aquaculture 106, 89-97.

Ruiz, C., Abad, M., Sedano, F., Garcia-Martin, L.O., Sanchez Lopez, J.L. (1992) Influence of seasonal environmental changes on the gamete production and biochemical composition of Crassostrea gigas (Thunberg) in suspended culture in El Grove, Galicia, Spain. J. Exp. Mar. Biol. Ecol. 155, 249-262.

Shaw, E C 3attle, H.I. (1957) The gross and microscopic anatomy of the digestive tract of the oyster Crassostrea virginica (Gmelin). Can. J. Zool. 35, 325-347.

Soletchnik, P., Faury, N., Razet, D., Goulletquer, P. (1998) Hydrobiology of the MarennesOleron Bay. Seasonal indices and analysis of trends from 1978 to 1995. Hydrobiologia 386, 1-3.

Steele, S., Mulcahy, M.F. (1999) Gametogenesis of the oyster Crassostrea gigas in southern Ireland. J. Mar. Biol. Assoc. U.K. 70, 673-686.

Utting, S.D., Millican, P.F. (1997) Techniques for the hatchery conditioning of bivalve broodstocks and the subsequent effect on egg quality and larval viability. Aquaculture 155, 47-56.

Wilson, J. (1981) Hatchery rearing of Ostrea edulis and Crassostrea gigas, Ireland, 32 pp. 